\title{
Editorial \\ Innovation in Propagation and Cultivation of Ornamental Plants
}

\author{
Jean Carlos Cardoso $1, *(\mathbb{1})$ and Wagner Aparecido Vendrame ${ }^{2}(\mathbb{D}$ \\ 1 Laboratory of Plant Physiology and Tissue Culture, Department of Biotechnology, Plant and Animal \\ Production, Center of Agricultural Sciences, Federal University of São Carlos, Araras 13600-970, SP, Brazil \\ 2 Environmental Horticulture Department, Institute of Food and Agricultural Sciences, University of Florida, \\ Gainesville, FL 32611, USA; vendrame@ufl.edu \\ * Correspondence: jeancardoso@ufscar.br
}

Citation: Cardoso, J.C.; Vendrame,

W.A. Innovation in Propagation

and Cultivation of Ornamental

Plants. Horticulturae 2022, 8, 229.

https://doi.org/10.3390/

horticulturae 8030229

Received: 2 March 2022

Accepted: 3 March 2022

Published: 7 March 2022

Publisher's Note: MDPI stays neutral with regard to jurisdictional claims in published maps and institutional affiliations.

Copyright: (C) 2022 by the authors. Licensee MDPI, Basel, Switzerland This article is an open access article distributed under the terms and conditions of the Creative Commons Attribution (CC BY) license (https:// creativecommons.org/licenses/by/ $4.0 /)$.

\section{Introduction and Special Issue Overview}

Ornamental plants are constantly being improved by new technologies and cultivation systems to provide new, high-quality plant material for one of the most demanding markets in the horticulture sector. In addition, the ornamental production sector faces several challenges, such as an increase in costs of production, new and old pests and diseases, climate change and the need to adapt to environmental stresses, the need for conservation and environmental protection, and competition with other food and energy crops in terms of areas and natural resources.

Therefore, innovative ideas and new technologies for use in the cultivation and propagation of ornamental plants are needed to support existing practices, as well as to develop the next generation of cultivation systems with increased gains, including more efficient systems of propagation and cultivation at lower costs, associated with sustainable production and management practices.

In this Special Issue of Horticulturae, "Innovation in Propagation and Cultivation of Ornamental Plants", research regarding new systems and technologies for use in the propagation and cultivation of ornamental plants is presented as an intersection of three main areas, as illustrated in the graphical abstract below. These include sustainability (sustainable production and best management practices), cultivation and propagation efficiency (techniques for improvement and increases in efficiency practices), and innovative technologies (from advanced breeding and genetic improvement techniques to automation and robotics).

\section{Old Problems That Persist and New Associated Challenges}

Among the major challenges in floriculture that continue to affect flower production and cultivation worldwide are: the exploitation and international commercialization of wild ornamental species considered threatened, endangered, or at risk of extinction [1]; the great diversity of species and cultivars in the hands of a few breeding companies located in developed countries; the occurrence of pests and diseases that have a great impact on the productivity and quality of final products and have a large number of hosts and the ability to acquire resistance to multiple active ingredients; the recent and constant change in climatic conditions, including temperature extremes and water scarcity in producing regions; and the current concern with sustainability and the need to adapt the production chain, from seed to after-sales of flowers and ornamental plants.

Regarding the commercialization of wild species, the expansion of the international market for 'rare' plants, which is associated with collection, has worryingly increased the overcollection of species considered threatened from natural habitats, which are considered as 'trophies' in amateur and private cultivations worldwide [2]. This exploitation has been expanded by the international online commerce and social media that promotes a strange 
feeling that the ex situ and private cultivation of endangered plants can be dealt with naturally and without legal consequences. Just as an example, a simple Google ${ }^{\circledR}$ search using the keyword Philodendron spiritus-sancti returns results of 'trophies' displayed by their 'owners'. This is an endemic plant species native to a restricted area of the state of Espírito Santo, Brazil, and its occurrence in nature has not been reported since 2000 [3]. In addition to this, this market of ornamental plants is still augmented by international trade, mostly online, which puts not only biodiversity at risk, but also phytosanitary issues associated with the unintentional transportation of pests and pathogens [4].

The large concentration of ornamental plant germplasm within a few private breeding companies (also called breeders) located in economically developed countries results in a highly profitable market of plants, which were obtained from the biodiversity found in tropical and underdeveloped countries to build their catalog of commercial cultivars. These improved cultivars are available worldwide for growers, including those from wild species, from which royalties are charged for their use and commercialization. This impact is further enhanced by the fact that most underdeveloped countries do not have current technologies for use in the large-scale propagation of plants (cloning), by which the use of modern techniques, such as micropropagation and somatic embryogenesis, allow superior cultivars to be propagated in different ways, efficiently allowing for their commercial production.

One problem in third-world floriculture is the expansion of some important pests and diseases in the cultivation of flowers and ornamental plants, with emphasis on: fungi of the genus Fusarium, which causes different symptoms according to the host, such as wilt, meltdown, and rot [5,6], and Botrytis cinerea [7] which causes the Botrytis blight disease or grey mold, which mainly affects the quality of flowers by the presence of small and numerous brown spots in flowers; thrips pests, which cause damage, especially to flowers, and can be vectors of viruses and other diseases; and viruses, which can be transmitted by pests or cutting tools. In these cases, the biggest challenge is the difficulty in controlling these pathogens in production systems, especially due to the large number of hosts and the high ability of pathogens and pests to acquire resistance to pesticides, which is seen in fungi and thrips, and the worldwide spread of viruses of great relevance to floriculture.

Regarding sustainability, floriculture is one of the agriculture sectors that uses a vast array of resources, such energy (heat, gas, electricity, etc.), as water (irrigation, mist systems, etc.) and fertilizers, growing materials (potting mixes), propagation materials (plugs, seeds, cutting, etc.), and products with high risks of pollution, such as plastics, packaging materials, and pesticides. An important tool for evaluation of the environmental impact of horticultural products is life cycle assessment (LCA). For floriculture products, that includes inputs (energy and materials) and outputs (releases in air, water, soil, etc.) throughout the production process, such as production and delivery, cultivation, postharvest handling, and transportation. LCA can be used to evaluate sustainable practices [8].

\section{Some Solutions and Practices That Create New Perspectives}

Considering the current problems and challenges, new solutions and practices are needed to create new perspectives with regard to the sustainable, large-scale, commercial production of ornamental plants. Some of these new solutions are already in development.

FloraGuard is a current project whose main objectives are to track, provide information, strengthen legislation, and explore strategies to combat the illegal online market of endangered plants [9]. This initiative should create solutions that will reduce the overcollection and commercialization of plants considered threatened or endangered that are illegally removed from their natural habitats.

The development of genetic improvement programs for flowers and ornamental plants by countries that use native species has been an interesting strategy that has enabled new cultivars to be obtained that are better adapted to their place of cultivation and that require fewer inputs and fewer changes in environmental conditions for their cultivation [10], thus providing technological gains, a reduction in the usage of resources, and greater sustainability to the production system. Another important concept is the development of 
cultivars of flowers and ornamental plants, as well as food crops, based on local conditions and species/varieties that require fewer inputs and technologies [11,12]. These strategies are important in terms of both increasing sustainability and adaptability to climate change conditions based on strategies for the development of cultivars resistant to abiotic stresses, such as high temperatures and drought conditions.

In addition, biotechnological tools for use in the breeding and propagation of ornamental plants should also include the optimization of micropropagation protocols and increase the importance and application of somatic embryogenesis for flowers and other ornamental plants. The combination of conventional and biotechnological breeding and propagation tools may increase efficiency in terms of the production of new cultivars and large-scale systems for efficient mass clonal plant propagation. Plant tissue culture tools, such as somatic embryogenesis, are also important strategies for the production of virus-free and high-quality plantlets for ornamental cultivation systems [13].

Phytosanitary problems associated with the production of ornamental plants are at an era of technological revolution. Using the pathogenic fungi of the genus Botrytis as an example, efforts have been made toward the integration of biotechnological and genetic engineering tools, including transgenics and omics [14], in addition to the use of management techniques or best management practices that are considered to be more sustainable, such as the use of beneficial microorganisms [15] and applications of calcium under spray on flowers [16] as compared to simple applications of pesticides.

The collection of rainwater from the upper face of greenhouses, which can be achieved using gutters attached to a storage tank, has been a strategy used by flower growers to irrigate plants during the driest times of the year. Another alternative, the reuse of water from sewage treatment, when used safely, can be an excellent alternative that can manage water availability for irrigation, especially considering the production of ornamental plants for inedible purposes, serving as a source of water and also reducing the need for mineral fertilizers. In addition, other organic residues from industry, such as organic residues or domestic sewage, or even from the production of flowers, require the development of processes, such as composting, that enable their biotransformation and can be efficiently and safely used, aiming to replace mineral fertilizers.

Finally, strategies such as the genetic transformation of ornamental plants must go beyond the commercial aspects, solving production and ornamentation problems, but also problems associated with sustainability. It would be very interesting to see transgenic plants with resistance to saline waters, which would allow the production of flowers using brackish water, or even saline sea water.

\section{Conclusions}

The cultivation of ornamental plants involves the science and art of breeding, propagating, and maintaining plants to enhance the human and natural environment. The use of new technologies has provided advancements in ornamental production systems. However, challenges still exist: issues surrounding the illegal overcollection of plants from their native habitats, sustainable production with a reduction in inputs and the development of more resilient cultivars, and the best management practices toward the control of pests and diseases must be addressed. The use of new and alternative technologies, including advanced omics and biotechnology tools, may assist in solving some of these challenges while improving the large-scale, sustainable production of ornamental plants.

Author Contributions: J.C.C. and W.A.V. conceptualize, wrote, revised and finally edited the paper. All authors have read and agreed to the published version of the manuscript.

Funding: This research was supported by the Sao Paulo Research Foundation (FAPESP, Brazil), grant number 2018/20673-3 and the Conselho Nacional de Desenvolvimento Científico e Tecnológico (CNPQ, Brazil), grant number 311083/2018-8. This work was supported by the USDA National Institute of Food and Agriculture, Hatch project 1012202.

Institutional Review Board Statement: Not applicable. 
Informed Consent Statement: Not applicable.

Conflicts of Interest: The authors declare no conflict of interest.

\section{References}

1. IUCN. Illegal Wildlife Trade Endangers Plants-But Few Are Listening. 2018. Available online: https://www.iucn.org/news/ species /201810/illegal-wildlife-trade-endangers-plants-few-are-listening (accessed on 18 February 2022).

2. Goettsch, B.; Hilton-Taylor, C.; Cruz-Piñón, G.; Duffy, J.P.; Frances, A.; Hernández, H.M.; Inger, R.; Pollock, C.; Schipper, J.; Superina, M.; et al. High proportion of cactus species threatened with extinction. Nat. Plants 2015, 1, 15142. [CrossRef] [PubMed]

3. CNCFlora. Philodendron Spiritus-Sancti in Lista Vermelha da Flora Brasileira Versão 2012.2 Centro Nacional de Conservação da Flora. Available online: http:/ / cncflora.jbrj.gov.br/portal/pt-br/profile/Philodendron\%20spiritus-sancti (accessed on 18 February 2022).

4. Lavorgna, A.; Sajeva, M. Studying Illegal Online Trades in Plants: Market Characteristics, Organisational and Behavioural Aspects, and Policing Challenges. Eur. J. Crim. Policy Res. 2021, 27, 451-470. [CrossRef]

5. Matić, S.; Gilardi, G.; Gullino, M.L.; Garibaldi, A. Evidence for an expanded host range of Fusarium oxysporum f. sp. chrysanthemi. J. Plant Pathol. 2018, 100, 97-104. [CrossRef]

6. Bika, R.; Baysal-Gurel, F. Identification of Fusarium commune, the Causal Agent of Postharvest Zinnia Meltdown Disease in Tennessee. HortTechnology 2021, 31, 432-438. [CrossRef]

7. Bika, R.; Baysal-Gurel, F.; Jennings, C. Botrytis cinerea management in ornamental production: A continuous battle. Can. J. Plant Path. 2021, 43, 345-365. [CrossRef]

8. Darras, A. Implementation of sustainable practices to ornamental plant cultivation worldwide: A critical review. Agronomy 2020, 10, 1570. [CrossRef]

9. Lavorgna, A.; Middleton, S.E.; Pickering, B.; Neumann, G. FloraGuard: Tackling the Online Illegal Trade in Endangered Plants Through a Cross-Disciplinary ICT-Enabled Methodology. J. Contemp. Crim. Justice 2020, 36, 428-450. [CrossRef]

10. Cardoso, J.C.; Martinelli, A.P.; da Silva, J.A.T. A novel approach for the selection of Cattleya hybrids for precocious and season-independent flowering. Euphytica 2016, 210, 143-150. [CrossRef]

11. Singh, R.P.; Chintagunta, A.D.; Agarwal, D.K.; Kureel, R.S.; Jeevan Kumar, S.P. Varietal replacement rate: Prospects and challenges for global food security. Glob. Food Secur. 2020, 25, 100324. [CrossRef]

12. Kogo, B.K.; Kumar, L.; Koech, R. Climate change and variability in Kenya: A review of impacts on agriculture and food security. Environ. Dev. Sustain. 2021, 23, 23-43. [CrossRef]

13. Almeida, N.V.; Rivas, E.B.; Cardoso, J.C. Somatic embryogenesis from flower tepals of Hippeastrum aiming regeneration of virus-free plants. Plant Sci. 2022, 317, 111191. [CrossRef] [PubMed]

14. Cui, Q.; Liu, Q.; Gao, X.; Yan, X.; Jia, G.-X. Trascriptome-based identification of genes related to resistance against Botrytis elliptica in Lilium regale. Can. J. Plant Sci. 2017, 98, 1058-1071. [CrossRef]

15. South, K.A.; Hand, F.P.; Jone, M.L. Beneficial bacteria identified for the control of Botrytis cinerea in petunia greenhouse production. Plant Dis. 2020, 104, 1801-1810. [CrossRef] [PubMed]

16. Bennett, K.; Vargo, M.; Schnabel, G.; Faust, J.E. Calcium Application Method Impacts Botrytis Blight Severity on Petunia Flowers. HortScience 2020, 55, 192-195. [CrossRef] 